\title{
The Contribution Of Business Units To Overall Company Customer Satisfaction And Profitability
}

Liezel Alsemgeest, University of the Free State, South Africa A.v.A Smit, University of the Free State, South Africa

\begin{abstract}
The relationship between customer satisfaction and profitability is well-researched and accepted. There seems to be a lack of information on companies with business units and how satisfaction with these business units affects the business units' profitability and the overall customer satisfaction with the company. The article aims to determine whether customer satisfaction can be used as a predictor of the level of profitability a business unit should achieve and how this impacts on the company as a whole. The study is of a quantitative nature and uses both questionnaires and financial data. All active customers of a major agricultural business in Central South Africa were approached to determine customer satisfaction. Published financial reports over a five-year period provided the contribution to net profit data for each business unit. The results indicated that there is a definite relationship between the business unit performance from a customer satisfaction standpoint and profitability, with a few exceptions. However, the level of profitability could not be predicted as all of the business units had relatively high levels of customer satisfaction, but profitability spanned a wide range. Business units with the least satisfied customers have a bigger impact on overall customer satisfaction, indicating that in order to reach higher profitability levels, the main focus should reside with the worst performing business units. The greater good of the company should be paramount for all the business units, as the 'bad apples' can have an inflated negative impact on overall customer satisfaction and affect other business units adversely.
\end{abstract}

Keywords: Customer Satisfaction; Profitability; Business Units; Agricultural Businesses

\section{INTRODUCTION}

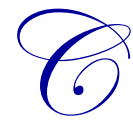

ustomer satisfaction and profitability is like love and marriage - "you can't have one without the other." The relationship between these two variables has been researched exhaustively and has been accepted widely. The majority of businesses are concerned with satisfying both themselves and their customers. Customers are satisfied when they receive good quality products and services at fair prices, while the business would be satisfied if it is profitable (Helgesen, 2006). Other factors such as the price of products, product quality, service quality (Nowak \& Washburn, 1998) and personnel efficiency (Adomaitiene \& Slatkeviciene, 2008) also impact on customer satisfaction. Customer satisfaction leads to loyalty, which means the customer would be retained and through repeat purchases, cash flow would increase. In this way, the market value of the business would increase and this would lead to higher levels of profitability (Luo \& Bhattacharya, 2006). Traditional customer satisfaction studies have been using the well-established SERVQUAL method (Parasuraman, Zeithaml \& Berry, 1994). There are various disadvantages to this specific method, the biggest of which is that it mainly measures satisfaction regarding service, while there are various other variables such as price, product and personnel that could impact on the satisfaction of the customer (Miller \& Brooks, 2010). Therefore, in order to include all of the necessary variables that result in customer satisfaction, it is necessary to use a different approach in testing customer satisfaction. 
The majority of research focussing on the relationship between customer satisfaction and profitability concentrate on companies as a whole. However, there tends to be a lack of information with regard to the relationship between these two variables when it comes to companies with different business units. These units are managed and run as individual businesses themselves and all form part of the 'umbrella' organization. A good example of such a kind of business would be an agribusiness, which has farmers as customers that make use of the various business units such as retail shops, grain marketing, financing, insurance and so forth (Ortmann \& King, 2007). The customers of an agribusiness are also fairly homogenous (from the same customer base) and the farmers make use of the business units to various degrees, which provide a unique opportunity to test their customer satisfaction within various business units.

Recognizing that there is a link between customer satisfaction and profitability of a company, the objective of this article is to determine the relevance of using customer satisfaction as a predictor for profitability. Not all business units are equal; therefore, it is necessary to establish which business unit's performance (customer satisfaction) impacts more on the overall customer satisfaction with the company, which will ultimately lead to greater profitability for the company as a whole. In other words, is the whole greater than the sum of its parts? The reasoning behind this enquiry is to gain insight into companies that have various business units that perform to various degrees, both in terms of customer satisfaction and profitability, and how it relates to the customer satisfaction experience regarding the company as a whole.

The article structure proceeds with a review of relevant literature concerning customer satisfaction, customer loyalty - specifically repurchase intentions and customer retention - and lastly profitability. The research method used to collect the relevant data was a survey distributed to farmers in Central South Africa in order to collect customer satisfaction data. The financial data were acquired by using published financial reports. The findings and possible implications will be discussed and, lastly, concluding remarks and recommendations will be made.

\section{LITERATURE REVIEW}

In order to fathom the relationship between customer satisfaction and profitability, it is necessary to identify the connection between customer satisfaction, customer loyalty (by means of repurchase intentions and customer retention), customer profitability and lastly business profitability.

\section{Customer Satisfaction}

Customer satisfaction is one of the most important factors in any organization. It has been determined that it costs six times more to acquire a new customer than to retain an existing one. It is, therefore, of utmost importance to treasure customers and keep them as happy as possible (Prabhakar, 2007). Oliver (2009) explains that customer satisfaction is the "fulfilment response" from the customers' point of view. It is the judgement made by the customer whether a specific product or service provides him/her with a pleasurable level of fulfilment, also indicating underfulfilment or over-fulfilment.

Before the latter part of the 1990s, customer satisfaction was only considered and measured for the particular product or service the customer acquired, therefore only "post-purchase evaluative judgments concerning specific purchase decisions" were considered. Lately, customer satisfaction is more concerned with the customers' previous experience of the company and the product or service collectively. This approach thus implies that it is better to measure overall satisfaction, rather than just customer intention or behaviour (Bodet, 2008).

An individual that uses a business once (one transaction), can only judge satisfaction on account of the performance of that one service encounter; therefore, satisfaction centres upon transaction-specific satisfaction. An individual that has made use of the business over an accumulated time will use the performance history of the business when judging satisfaction and therefore would concentrate on a summary of all past transactions and service encounters, which could lead to a positive attitude and loyalty towards the business on the part of the customer (Oliver, 2009). This would be the case in this specific research study, as the farmers are customers of the agricultural business over an extended period of time. Satisfied customers could become loyal customers; and every 
opportunity to interact with the customer provides the business with the prospect of creating value due to a longlasting relationship (Richards \& Jones, 2008).

\section{Customer Loyalty}

According to Fornell, Mithas, Morgesson and Krishnan (2006), the more loyal a customer is to a particular business, the longer the customer would frequent the business and consequently revenue would increase due to the constant support of the customer. It has been suggested in various studies that the longer a customer stays with a particular business, the more loyal that customer is and the more profitable the customer becomes to the business, as future cash flows are secured (Ranaweera, 2007). In establishing a relationship between customer satisfaction and customer loyalty, it is essential to consider repurchase intentions, as well as customer retention in an attempt to illustrate the progress from customer satisfaction to, ultimately, profitability.

The more satisfied a customer is, the stronger the potential for repurchase intentions. A study done in 1996 found that customers who indicated they were highly satisfied were six times more likely to use the company again compared to individuals that were merely satisfied. It, therefore, follows that highly satisfied customers have higher repurchase intentions than those individuals that are merely satisfied. This finding indicates that customer satisfaction can have a substantial impact on profitability (Zeithaml, 2000). The link between customer satisfaction and financial performance through increased repurchase intentions and enhanced business reputation can be explained as follows:

Customer satisfaction leads to an increase in repurchase intentions as well as the favourable reputation of the business. As repurchase intentions are improved, it also leads to an increase in the future revenue obtained from existing customers, as these customers would remain loyal to the business and support the business repeatedly. This would lead to an increase in future customer profitability and subsequently an increase in future financial performance. Also, an increase in repurchase intentions could have either a positive or negative effect on the costs associated with retaining existing customers. If customer satisfaction has an enhanced effect on repurchase intentions, this would - in the majority of cases - lead to a decrease in cost in holding on to the existing customers and when revenue increases, while costs decrease, this would lead to future customer profitability and ultimately future business profitability (Yu, 2007).

Customer satisfaction also has a positive effect on business reputation, which would impact efforts to reach new customers constructively. If new customers are acquired as a result of increased business reputation, then future revenue will be acquired and this would impact positively on financial performance (Yu, 2007). These results are supported by Guo, Kumar and Jiraporn (2004), who explain two ways in which customer satisfaction can affect sales. The first is that it is generally accepted that increased customer satisfaction leads to customer loyalty, while customer loyalty is assumed to lead to increased sales. Secondly, a business that has a high level of customer satisfaction would also develop a good reputation through word-of-mouth, and this could lead to acquiring new customers.

According to Zeithaml (2000) there are several ways in which customer retention could lead to increased profits. Firstly, by retaining customers a company could show a reduction in costs as it has been established that it costs more to acquire new customers than to retain existing ones. Secondly, an increased volume of purchases is likely if the customer is satisfied with the specific business, product and/or services provided. Thirdly, the business could charge premium prices if customers are loyal to the business and lastly, the retained customers could engage in increased word-of-mouth marketing. By providing service quality to customers, customer satisfaction is increased and this leads to customer retention. Keeping existing customers happy and retaining them are perceived to be a defensive marketing strategy. Customer retention is also a factor of customer relationship management, which is referred to as a part of defensive marketing (Helgesen, 2006).

In an effort to link customer retention to increased profits, there are intervening factors, such as a decrease in costs to retain these existing customers, an increase in volume of purchases, price premiums can be introduced; and satisfied and retained customers are more likely to impart positive word-of-mouth messages. On the other hand, by acquiring new customers though service quality, a business is employing an offensive marketing strategy. New 
customers equate to an increase in market share through an increase in volume purchases and premium prices that would push profits upwards (Zeithaml, 2000). According to $\mathrm{Yu}$ (2007) an "enhanced reputation can further aid in introducing new products by providing instant awareness and this lowers costs of attracting new customers". These three factors would lead to increased sales, which in turn would lead to increased profits. Customer satisfaction thus leads to customer loyalty by increasing both repurchase intentions and maintaining relations with existing customers. The following section explores the relationship between customer loyalty and customer profitability.

\section{Profitability}

The dominant view in research (Ranaweera, 2007) is that long-term customers (customers that have developed a relationship with the business over time) who are satisfied will be loyal to the business and generate more profit because they are accustomed to the service, use the service more and are less price sensitive and, thus, business can change more. Furthermore, extra business is brought through referrals and the company is more profitable because acquiring new customers is more costly than retaining them.

Research so far has mainly focused on customer satisfaction and the link to retaining customers. However, it seems that a key determinant of profitability is retaining customers. It has been established that customer retention alone does not necessarily result in "loyal customers costing less to serve, paying higher prices for the same bundle of services, or marketing the company through word-of-mouth".

According to Anderson, Fornell and Mazvancheryl (2004) customer satisfaction ensures customer retention, which in turn leads to the following outcomes:

- It secures future revenue;

- It reduces the costs of future customer transactions (such as those associated with communication, sales and service);

- $\quad$ Net cash flows increase;

- $\quad$ A more stable customer base providing a relatively predictable level of future revenue;

- $\quad$ Customers keep returning to the business; and

- Shareholder value is positively affected as volatility and risk associated with future revenues are reduced.

Various studies (e.g. Yu, 2007 and Ranaweera, 2007) have shown that customer satisfaction leads to an increase in profits due to less price sensitivity of customers, increased referrals and a reduction in costs, which could lead to both an increase in profit (and therefore dividends) and growth.

Customer loyalty cannot be measured by only looking at customer retention as, in most cases, a customer would rather change his/her spending with a particular business due to dissatisfaction than leave the business altogether. It is, thus, of great importance to businesses to ensure that customers spend their maximum share-ofwallet and this goal could be more important than simply retaining customers (Keiningham, Perkins-Munn, Aksoy \& Estrin, 2005).

\section{METHOD}

The research design employed in this study was of a quantitative nature, making use of both questionnaires and financial data in order to reach the stated objectives. The target population comprised all active customers of a major agricultural business in Central South Africa that provide R100 000 or more volume of business to the agricultural business. In order to make provision for non-response, it was decided to use the whole population. This decision eliminated the use of a population sample and is therefore considered to be a census. The census method was used due to the fact that the agricultural business consists of various business units with customers making use of the business unit to varying degrees. In addition, when populations are relatively small and easily accessible, accuracy will be increased by using a census rather than sampling (Cooper \& Schindler, 2006). The total population was 963 customers and a total of 345 useable questionnaires were received. The response rate was thus $35.8 \%$ of the total population. 
The measuring instrument for the customer satisfaction part of the data was a mailed questionnaire that was sent to the respondents with an enclosed envelope. The traditional SERVQUAL questionnaire was not used in this particular study, as discussed earlier, due to the many disadvantages the instrument pose. The questionnaire was simplified to obtain the respondents' straightforward level of satisfaction. The questionnaire made use of closedended questions and 9-point Likert scale response options and aimed to determine the level of satisfaction customers experience with regard to the various business units and the company as a whole. Questions related to specific issues in each business unit, such as satisfaction regarding prices, availability and quality of products, service quality and so forth, as well as their satisfaction level with each business unit. The reason behind using a 9-point Likert-scale is to allow finer classification within the three broad response options - poor, average and good. The questionnaires' reliability was tested through internal consistency and the Cronbach Alpha test indicated a result of 0.982 . This indicates that the questions and questionnaire as a whole has a very high internal consistency and therefore are highly reliable. Validity was tested by making use of construct validity and the results of the Kaiser-Meyer-Olken (KOM) and Bartlett's test for item validity were used. The results indicate that the KMO is very high for each question (all above 0.788 ) and the results are all statistically significant - therefore the validity is high.

The profitability information was gathered through published financial reports of the agricultural business over a five-year period. The best encompassing measure to use to measure profitability is the return on assets ratio (ROA). Unfortunately this could not be measured accurately due to the fact that certain assets are used by multiple business units. Due to this overlap, it was decided to rather use the business units' contribution towards the net profit (as a percentage) of the agricultural business to find a more accurate measure.

The data were analysed by using descriptive statistics, as well as calculating correlations, coefficients of determination, means and regression analysis.

\section{RESULTS}

The demographic profile of the respondents will be followed by customer satisfaction and contribution towards net profit results.

\section{Demographic profile of the respondents}

The respondents were asked to indicate the farming activity they are mainly involved in, the total years' of farming experience they have, as well as their age. The respondents were also classified according to the size of their contributions to the agricultural business into small customers (between R100 000 and R250 000 volume of business), medium customers (between R250 001 and R650 000 volume of business) and big customers (more than R650 001 volume of business).

The respondents had to indicate what type of farming operation they are mainly involved in. The majority of the respondents were mainly grain farmers $(45.0 \%)$, while a smaller percentage $(31.0 \%)$ are mainly livestock farmers and the remaining $24.0 \%$ an even split between grain and livestock.

The majority (79\%) of the respondents were above the age of 46 . The average age of the respondents was established to be 53.6 years. It is worth noting that less than $2 \%$ of the respondents were 30 and younger. This could be an indication that younger people might be avoiding farming as a career choice or that the younger customers are not yet big enough to contribute R100 000 and more volume of business to the organization.

Respondents were asked to indicate the number of years that they have been farming to give an indication of their experience. The majority of the respondents (61.2\%) have more than 26 years' experience, while a minority of $2.6 \%$ has less than 5 years' experience. It was found that the average years' experience is 29.4 years. It could, therefore, be assumed that the respondents have adequate knowledge with regard to agricultural businesses.

The three groups were roughly equally distributed according to the relative size of their contributions towards the agricultural business. Small customers are the biggest group (38.8\%), while $33.3 \%$ were medium customers and $27.8 \%$ big customers. 


\section{Customer Satisfaction and Profitability Results}

The following section provides empirical data with regard to customer satisfaction pertaining to each individual business unit, as well as that of the company as a whole. The composition of net profit according to the financial reports will then be demonstrated. The customer satisfaction and profitability performance will then be compared with each other with the aid of a graph. Lastly, the correlation between the various business units and the company as a whole will be discussed.

Table 1: Business units' customer satisfaction

\begin{tabular}{|l|c|c|c|c|c|}
\hline \multicolumn{1}{|c|}{ Business units } & Poor & Average & Good & Mean & Rank \\
\hline Retail shops & $3.8 \%$ & $33.1 \%$ & $63.0 \%$ & 6.7278 & 4 \\
\hline Grain storage & $2.0 \%$ & $17.6 \%$ & $80.4 \%$ & 7.3333 & 1 \\
\hline Grain marketing & $6.8 \%$ & $33.7 \%$ & $59.5 \%$ & 6.5895 & 5 \\
\hline Financing & $7.9 \%$ & $23.6 \%$ & $68.5 \%$ & 6.7879 & 3 \\
\hline Mechanization (workshops) & $10.9 \%$ & $44.6 \%$ & $44.6 \%$ & 5.9657 & 8 \\
\hline Mechanization (spare parts) & $12.7 \%$ & $38.8 \%$ & $48.5 \%$ & 5.9799 & 7 \\
\hline Mechanization (whole goods) & $11.0 \%$ & $33.1 \%$ & $55.8 \%$ & 6.2652 & 6 \\
\hline Insurance & $2.4 \%$ & $30.2 \%$ & $67.5 \%$ & 6.9206 & 2 \\
\hline
\end{tabular}

As indicated in Table 1 all the business units have mean values above the middle value of 5.00, indicating that all units' performance are above average to good. Grain storage performed the best of all of the business units with a mean of 7.3333 and $80.4 \%$ of the respondents indicated that this business unit performs well. This is also a good result as the majority of the respondents (almost 75\%) make use of this specific business unit. Insurance showed a very high mean of 6.9206, even though only $36 \%$ of the respondents make use of this business unit. All three mechanization business units (workshops, spare parts and whole goods) performed the worst of all the services provided by the agricultural business and these three business units also have the highest percentage of respondents indicating that they perform poorly. This could be a concern as mechanization (spare parts) is used by almost $90 \%$ of the respondents.

Table 2: Overall company customer satisfaction

\begin{tabular}{|l|c|c|c|c|}
\hline & Poor & Average & Good & Mean \\
\hline Agricultural business as a whole & $4.1 \%$ & $14.2 \%$ & $81.7 \%$ & 6.9354 \\
\hline
\end{tabular}

Table 2 gives an indication of how the respondents rated the agricultural business' performance as a whole. The results indicate a very good satisfaction level of performance by the majority of the respondents $(81.7 \%)$. The mean is high (6.9354) in comparison to the majority of the services provided; therefore, it can be assumed that the respondents regard the company as a whole to perform well above average.

Table 3 provides details with regard to the contribution of the various business units towards the composition of the agricultural business's net profit. The information spans a period of 5 years to ensure accuracy.

Table 3: Composition of net profit by the various business units

\begin{tabular}{|l|c|c|c|c|c|c|}
\hline \multicolumn{1}{|c|}{ Business units } & $\mathbf{2 0 0 5 / 2 0 0 6}$ & $\mathbf{2 0 0 6 / 2 0 0 7}$ & $\mathbf{2 0 0 7 / 2 0 0 8}$ & $\mathbf{2 0 0 8 / 2 0 0 9}$ & Average & Rank \\
\hline Retail shops & $9.5 \%$ & $16.2 \%$ & $13.0 \%$ & $9.2 \%$ & $12.0 \%$ & 4 \\
\hline Grain storage & $59.8 \%$ & $51.1 \%$ & $64.7 \%$ & $60.0 \%$ & $58.9 \%$ & 1 \\
\hline Grain marketing & $29.3 \%$ & $23.5 \%$ & $12.4 \%$ & $17.0 \%$ & $20.5 \%$ & 2 \\
\hline Financing & $15.4 \%$ & $17.2 \%$ & $8.2 \%$ & $10.9 \%$ & $12.9 \%$ & 3 \\
\hline Mechanization (workshops) & $-3.4 \%$ & $-2.2 \%$ & $-1.0 \%$ & $-0.6 \%$ & $-1.8 \%$ & 7 \\
\hline Mechanization (spare parts) & $-5.3 \%$ & $-2.2 \%$ & $1.4 \%$ & $2.7 \%$ & $-0.8 \%$ & 6 \\
\hline Mechanization (whole goods) & $-5.4 \%$ & $-4.1 \%$ & $0.4 \%$ & $-0.1 \%$ & $-2.3 \%$ & 8 \\
\hline Insurance & $0.3 \%$ & $0.6 \%$ & $0.9 \%$ & $1.0 \%$ & $0.7 \%$ & 5 \\
\hline
\end{tabular}

It is clear that grain storage contributed the lion share and therefore contributes the highest average percentage, while mechanization (workshops), mechanization (spare parts) and mechanization (whole goods) have actually been running at a loss on average over the past four years. 
The information from Table 1 (business units' customer satisfaction) can be converted to percentages by using the mean value minus 1 and dividing the answer by 8 (nine-point Likert scale minus 1). Table 4 presents the level of customer satisfaction of the various business units in percentage format, as well as the average contribution made by each business unit over the past 5 years. Since different numbers of customers make use of each business unit, the weighted contribution for each business unit was calculated.

Table 4: Contribution percentage of net profit and customer satisfaction percentage of the business units

\begin{tabular}{|c|c|c|c|c|}
\hline Business units & Contribution \% & $\begin{array}{c}\text { Contribution } \\
\text { rank }\end{array}$ & Performance \% & $\begin{array}{c}\begin{array}{c}\text { Performance } \\
\text { rank }\end{array} \\
\end{array}$ \\
\hline Retail shops & $11.83 \%$ & 1 & $71.6 \%$ & 4 \\
\hline Grain storage & $43.70 \%$ & 5 & $79.2 \%$ & 1 \\
\hline Grain marketing & $10.93 \%$ & 4 & $69.9 \%$ & 5 \\
\hline Financing & $6.00 \%$ & 2 & $72.3 \%$ & 3 \\
\hline Mechanization (workshops) & $-0.87 \%$ & 3 & $62.1 \%$ & 8 \\
\hline Mechanization (spare parts) & $-0.71 \%$ & 8 & $62.2 \%$ & 7 \\
\hline Mechanization (whole goods) & $-1.27 \%$ & 6 & $65.8 \%$ & 6 \\
\hline Insurance & $0.25 \%$ & 7 & $74.0 \%$ & 2 \\
\hline
\end{tabular}

By making use of a graph, the contribution percentage of net profit, as well as the customer satisfaction performance percentage can be compared. Figure 3 provides the graphical representation of these two types of percentages.

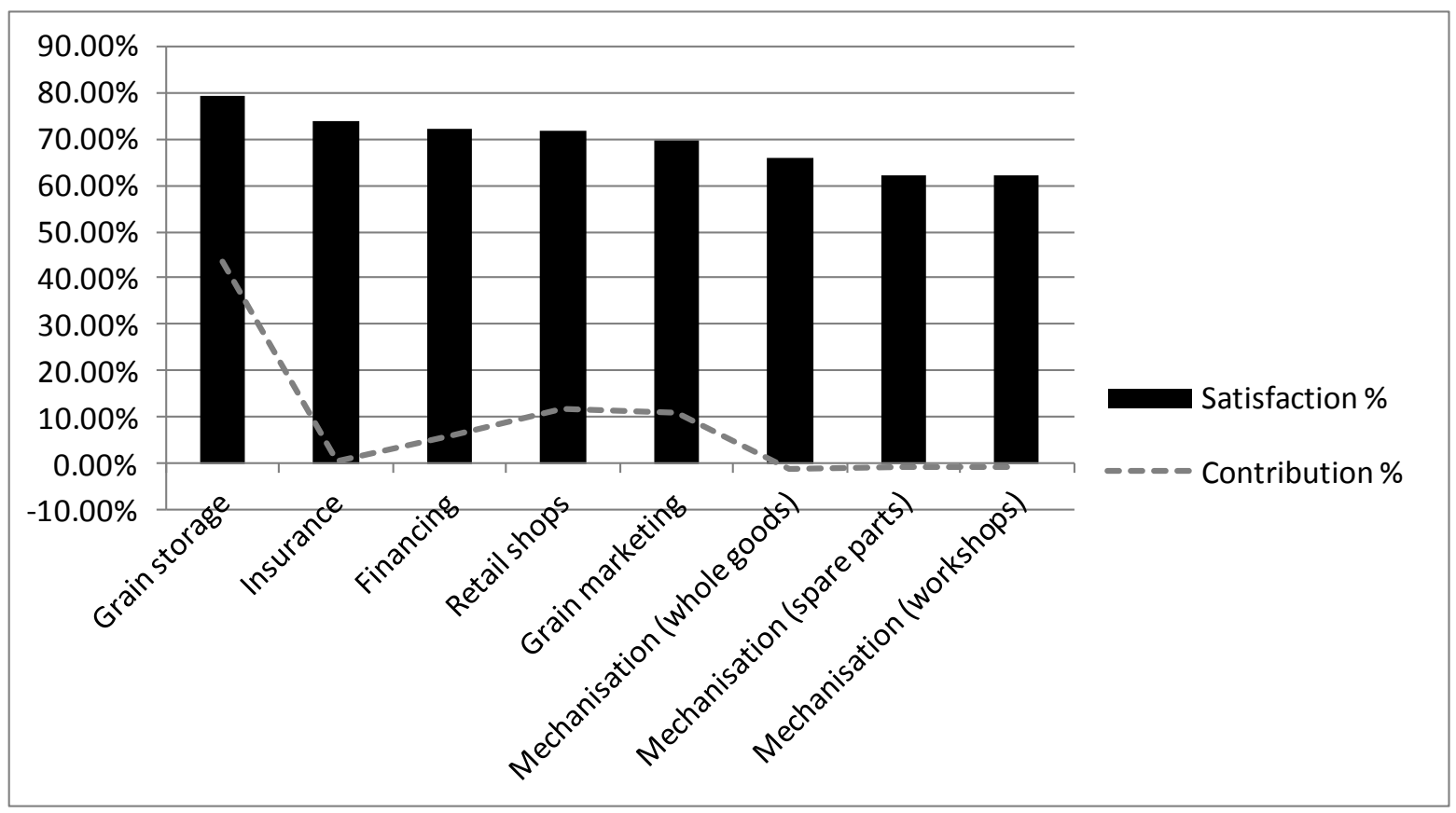

Figure 3: Graphical representation of the contribution percentage and the performance percentage of the business units

The business units were aligned from best performing to worst performing in terms of customer satisfaction. The graphical representation indicates that there could be a relationship between the contribution to net profit and customer satisfaction. Unfortunately, this could not be proven statistically as two different data sets were used (satisfaction survey and financial statements). However, the contribution percentage and the customer satisfaction percentage of each of the business units seem to follow the same movements. Even though insurance are the second best performing business unit in terms of customer satisfaction, the contribution towards net profit is very low. As mentioned before, only $36 \%$ of the respondents make use of this business unit, therefore the customer 
satisfaction performance and contribution towards net profit do not correlate. In the case of financing and mechanization (whole goods), however, when performance increased, the contribution to net profit decreased slightly. It can, therefore, be assumed that there seem to be a relationship in the majority of cases between the contribution that each business unit make to the agricultural business's net profit and the perception of performance that the respondents have towards the business units.

The last part of the empirical analysis will focus on determining how the customer satisfaction of each business unit impact on customer satisfaction with the overall company.

Table 5: Correlation between the overall customer satisfaction with each business unit with the customer satisfaction of the company as a whole

\begin{tabular}{|l|c|c|c|}
\hline \multicolumn{1}{|c|}{ Customer satisfaction } & Overall customer satisfaction with the company & \multicolumn{2}{c|}{$\mathbf{R}^{\mathbf{2}}$} \\
\hline Rank \\
\hline Retail shops & Sig & $32 \%$ & 1 \\
\hline Grain storage & $0.000^{*}$ & $7 \%$ & 6 \\
\hline Grain marketing & $0.000^{*}$ & $10 \%$ & 5 \\
\hline Financing & $0.000^{*}$ & $12 \%$ & 4 \\
\hline Mechanization (workshops) & $0.000^{*}$ & $20 \%$ & 2 \\
\hline Mechanization (spare parts) & $0.000^{*}$ & $20 \%$ & 2 \\
\hline Mechanization (whole goods) & $0.000^{*}$ & $20 \%$ & \\
\hline Insurance & $0.000^{*}$ & $19 \%$ & \\
\hline
\end{tabular}

*P-value is less than 0.01

The results in Figure 5 indicate that the customer satisfaction with every business unit correlated positively (not shown) and significantly with the customer satisfaction of the overall company. It can, therefore, be said that an improvement in the satisfaction of customers of any business unit will (to a greater or lesser extent) also improve the overall satisfaction with the company. The coefficient of determination $\left(\mathrm{R}^{2}\right)$ measures the strength of the correlation and the percentage indicates the change in the satisfaction of the overall company that can be accounted for by a change in the satisfaction of the specific business unit. It is, therefore, clear that a change in the satisfaction with retail shops will have most impact on the overall company and thus a change in the overall level of satisfaction with the company; $32 \%$ of that change can be explained by a change in the level of satisfaction with retail shops. All three mechanization business units (with a $\mathrm{R}^{2}$ of $20 \%$ ) are second and insurance third most influential. It is important to note that retail shops are used by more than $99 \%$ of the respondents, making it the most popular business unit. If retail shops are taken out of the equation, then the business units with the second highest coefficient of determination are the three mechanization units $(20 \%)$, which are the worst performing business units in terms of customer satisfaction. Interestingly, the business unit with the lowest coefficient of determination is grain storage (7\%), which is the best performing unit with regard to customer satisfaction. For the following analysis retail shops were excluded.

The following table indicates the results of linear regression between the overall level of satisfaction towards the company with all of the business units together. Only the significant relationships are displayed.

Table 6: Linear regression between overall level of satisfaction

towards each business unit with the satisfaction towards the company as a whole

\begin{tabular}{|l|c|c|}
\hline \multicolumn{1}{|c|}{ Overall performance of company } & Beta Coefficients & Sig. \\
\hline Mechanization (workshops) & 0.218 & 0.015 \\
\hline Insurance & 0.239 & 0.010 \\
\hline
\end{tabular}

The results indicate that in order to improve the customer satisfaction of the company as a whole, it is imperative to focus on mechanization (workshops) and insurance. The Beta Coefficient indicates the strength of the relationship. From the above it is clear that customer satisfaction with insurance has a slightly bigger impact on customer satisfaction with the company as a whole. These two business units are amongst the least profitable of all the business units. 


\section{DISCUSSION AND POSSIBLE IMPLICATIONS}

There is a definite link between customer satisfaction and profitability, as the literature suggests (Helgesen, 2006). The results indicate that there could be a link between how business units perform in terms of customer satisfaction and their contribution towards profitability. The best performing business unit (grain storage), had the highest level of customer satisfaction, as well as the biggest contribution towards net profit. As customer satisfaction declines in the business units, profitability also tends to decline, with a few exceptions. These results were expected, because the relationship between customer satisfaction and profitability is known (Anderson, et al., 2004).

The level of profitability that each unit contributes towards the company as a whole cannot be predicted, as some business units contribute on average more than $40 \%$ to the overall net profit, while others make a net loss. Conversely, the levels of customer satisfaction with the business units are above $60 \%$ in all cases, indicating aboveaverage customer satisfaction. Therefore, in the case of this specific company, customer satisfaction could not be used as a tool to predict the level of the profitability a particular business unit could achieve. This could be because the business units are unique and diverse. Also, the demographic profile of the respondents indicated that almost half of the respondents are mainly grain farmers, which would lead to a unit such as grain storage to perform financially better than other units. Therefore, all business units are not equal and although all business units' customer satisfaction is positively correlated towards overall customer satisfaction with the company, some business units can have a bigger influence on overall customer satisfaction.

The results indicated that, on average, a change in customer satisfaction with the worst performing business units in terms of profitability (mechanization and insurance) would cause a much bigger change in overall customer satisfaction. Also, a change in the customer satisfaction of the best performing business unit (grain storage) would create the smallest change in overall customer satisfaction. Therefore, increasing customer satisfaction with a 'bad apple' business unit would allow for a bigger advantage in increasing overall customer satisfaction than that of a business unit with highly satisfied customers. This indicates that in order to increase profitability of a company, overall customer satisfaction should be increased and this can be achieved by focussing firstly on the worst performing business units (in terms of customer satisfaction). The results suggests that in order to achieve greater customer satisfaction (and profitability) it is imperative for a company as a whole to aspire to elevate the worst performing business units and bring them closer to par. This could increase the overall customer satisfaction of the company, increase profitability and all business units will benefit from it. Negative feelings towards a specific business unit could escalate and affect the reputation of the company adversely, which would impact on the other business units as well.

Competition among business units, although healthy and necessary, could be problematic in requesting business units to help each other for the greater good of the company. The research was focussed on a company that operates in a unique environment and where the business units, although diverse, is related to each other (farming). In another industry, the results could look very different.

\section{CONCLUSION}

The results of this study indicate that in order for a company to achieve maximum profitability, it is necessary to increase customer satisfaction. For a company with diverse business units, this can be achieved by increasing the customer satisfaction related to the business units themselves. In a company with very diverse, but related business units, it might not be possible to predict the level of profitability a specific business unit could achieve. However, in order for a company to increase its overall customer satisfaction, the focus should reside with the worst performing business units (customer satisfaction), as any improvement in these would have the biggest impact on customer satisfaction with the company as a whole. The question was posed whether the whole is greater than the sum of its parts and from the standpoint of this study; the whole is definitely greater than the sum of its parts, as business units should rally together for the greater good of the company.

Future research could focus on companies with unrelated and independent business units or on other industries to determine whether customer satisfaction can predict their level of profitability. Customer satisfaction and profitability is like love and marriage, but it seems that in order to for a company to perform at the highest level, 
depending on the specific context in which it operates, more attention should be devoted to the weaknesses than to the strengths.

\section{AUTHOR INFORMATION}

Liezel Alsemgeest is a lecturer at the Centre for Financial Planning Law, University of the Free State, South Africa. She holds a PhD in Business Management from the University of the Free State that focuses on customer satisfaction in agricultural businesses. Her research areas are corporate finance, personal finance and agricultural businesses. E-mail: alsemgeestl@ufs.ac.za (Corresponding author)

A.v.A Smit is a professor of business management at the University of the Free State, South Africa. He is a specialist in the areas of financial management and entrepreneurship. E-mail: $\underline{\text { smitava@ufs.ac.za }}$

\section{REFERENCES}

1. Adomaitiene, R. \& Slatkeviciene, G. (2008). Employee Satisfaction and Service Quality in Contact Centres. Economics and Management, 13 770-775.

2. Anderson, E.W., Fornell, C. \& Mazvancheryl, S.K. (2004). Customer Satisfaction and Shareholder Value. Journal of Marketing, 68 172-185.

3. Bodet, G. (2008). Customer satisfaction and loyalty in service: Two concepts, four constructs, several relationships. Journal of Retailing and Consumer Services, 15 156-162.

4. Cooper, D.R. \& Schindler, P.S. (2006). Business Research Methods. 9th ed. New York: McGrawHill/Irwin.

5. Fornell, C., Mithas, S., Morgeson III, F.V. \& Krishnan, M.S. (2006). Customer Satisfaction and Stock Prices: High Returns, Low Risk. Journal of Marketing, 70 3-14.

6. Guo, C., Kumar, A. \& Jiraporn, P. (2004). Customer satisfaction and profitability: is there a lagged effect? Journal of Strategic Marketing, 12 129-144.

7. Helgesen, Ø. (2006). Are Loyal Customers Profitable? Customer Satisfaction, Customer (Action) Loyalty and Customer Profitability at the Individual Level. Journal of Marketing Management, 22 245-266.

8. Keiningham, T.L., Perkins-Munn, T., Aksoy, L. \& Estrin, D. (2005). Does customer satisfaction lead to profitability? The mediating role of share-of-wallet. Managing Service Quality, 15(2) 172-181.

9. Luo, X. \& Bhattacharya, C.B. (2006). Corporate Social Responsibility, Customer Satisfaction, and Market Value. Journal of Marketing, 70 1-18.

10. Miller, R.E. \& Brooks, N.G. (2010). Class Service Quality: Moving Beyond SERVQUAL. Information Systems Educators Conference. Nashville Tennessee, USA. Retrieved from: http://proc.isecon.org/2010/pdf/1394.pdf

11. Nowak, L.I. \& Washburn, J.H. (1998). Antecedents to client satisfaction in business services. The Journal of Services Marketing, 12(6) 441-452.

12. Oliver, R.L. (2009). Satisfaction: A Behavioral Perspective on the Consumer. 2nd ed. New York: M.E. Sharpe, Inc.

13. Ortmann, G.F. \& King, R.P. (2007). Agricultural Cooperatives I: History, Theory and Problems. Agrekon, 46(1) 40-68.

14. Parasuraman, A., Zeithaml, V.A. \& Berry, L.L. (1994). Alternative Scales for Measuring Service Quality: a Comparative Assessment Based on Psychometric and Diagnostic Criteria SERVQUAL: A Multiple-Item Scale for Measuring Consumer Perceptions of Service Quality. Journal of Retailing, 70(3) 201-230.

15. Prabhakar, A. (2007). Customer Satisfaction. Journal of the Quality Assurance Institute. 21(3) 5-10.

16. Ranaweera, C. (2007). Are satisfied long-term customers more profitable? Evidence from the telecommunication sector. Journal of Targeting, Measurement and Analysis for Marketing, 15(2) 113-120.

17. Richards, K.A. \& Jones, E. (2008). Customer Relationship Management: Finding Value Drivers. Industrial Marketing Management, 37 120-130.

18. Yu, S. (2007). An Empirical Investigation on the Economic Consequences of Customer Satisfaction. Total Quality Management, 18(5) 555-569.

19. Zeithaml, V.A. (2000). Service Quality, Profitability, and the Economic Worth of Customers: What We Know and What We Need to Learn. Journal of the Academy of Marketing Science, 28(1) 67-85. 